PNL-2280

UC-11

\title{
Comparative Biogeochemical Behaviors of Iron-55 and Stable Iron in the Marine Environment
}

W. C. Weimer

J. C. Langford

C. E. Jenkins

February 6, 1978

Pacific Northwest Laboratory

Richland, Washington 99352

Operated for the

U.S. Department of Energy by 
NOTICE

This report was prepared as an account of work sponsored by the United States Government. Neither the United States nor the Department of Energy, nor any of their employees, nor any of their contractors, subcontractors, or their employees, makes any warranty, express or implied, or assumes any legal liability or responsibility for the accuracy, completeness or usefulness of any information, apparatus, product or process disclosed, or represents that its use would not infringe privately owned rights.

The views, opinions and conclusions contained in this report are those of the contractor and do not necessarily represent those of the United States Government or the United States Department of Energy.

\author{
PACIFIC NORTHWEST LABORATORY \\ operated by \\ BATTELLE \\ for the \\ UNITED STATES DEP.ARTMENT OF ENERCY \\ Under Contract EY-76-C-06-1830
}

\begin{tabular}{|c|c|c|}
\hline \multicolumn{3}{|c|}{$\begin{array}{c}\text { Printed in the United States of Americ } \\
\text { Available from } \\
\text { National Technical Information Servic } \\
\text { United States Department of Commer } \\
5285 \text { Port Royal Road } \\
\text { Springfield. Virginia } 22751\end{array}$} \\
\hline Price: & Printed Cor & $\therefore$ Microfiche \\
\hline & •Pages & $\begin{array}{c}\text { NTIS } \\
\text { Selling Price }\end{array}$ \\
\hline & $001-025$ & $\$ 4.50$ \\
\hline & $026-050$ & 55.00 \\
\hline & $051-075$ & $\$ 5.50$ \\
\hline & $076-100$ & $\$ 6.00$ \\
\hline & $107-125$ & 36.50 \\
\hline & $125-150$ & $57: 00$ \\
\hline & $151-175$ & 57.75 \\
\hline & $176-200$ & $\mathbf{5 8 . 5 0}$ \\
\hline & $201-225$ & 50.75 \\
\hline & $226-250$ & 59.00 \\
\hline & $251-275$ & $\$ 10.00$ \\
\hline & $276-300$ & 510.25 \\
\hline
\end{tabular}




\section{5}

COMPARATIVE BIOGEOCHEMICAL BEHAVIORS OF IRON-55 AND

STABLE IRON IN THE

MARINE ENVIRONMENT

Prepared for the

U.S. Department of Energy

under Contract EY-76-C-06-1830

W. C. Weimer

J. C. Langford

C. E. Jenkins

February 6, 1978

PACIFIC NORTHWEST LABORATORY

Richland, Washington 99352

Operated by

BATTELLE MEMORIAL INSTITUTE 


\section{ABSTRACT}

Studies of atmospheric derosols have demonstrated that much of the ${ }^{55} \mathrm{Fe}$ associated with the aerosol input to the oceans is present as either an amorphous or hydrous iron oxide or as very small particulate species attached to the surfaces of the large aerosol particles. By comparison, nearly all of the stable iron is bound in the mineral phase of aerosol particles. This difference in the chemical and physical forms of the radioactive and stable iron isotopes results in the ${ }^{55} \mathrm{Fe}$ being more biologically available than is the stable iron. This difference in availability is responsible for the transfer of a much higher specific activity ${ }^{55} \mathrm{Fe}$ to certain ocear organisms and man relative to the specific activity of the total aerosol or of sea water. This differential biological uptake of the radioactive element and its stable element counterpart points out that natural levels of stable elements in the marine environment may not effectively dilute radioelements or other stable elements of anthropogenic sources. The effectiveness of dilution by natural sources depends on the chemical and physical forms of the materials in both the source terms and the receiving environments. The large 
difference in specific activities of ${ }^{55} \mathrm{Fe}$ in aerosols and sea water relative to ocean organisms reflects the independent behaviors of ${ }^{55} \mathrm{Fe}$ and stable iron.

\section{INTRODUCTION}

Since the beginning of nuclear testing, ${ }^{55} \mathrm{Fe}$ has constituted one of the major radioactive isotopes present in atmospheric fallout in the northern hemisphere. ${ }^{1}$ Iron-55 is produced during the detonation of nuclear devices by the neutron activation of stable iron both in the device structure and in any nearby soil. A large proportion of the ${ }^{55} \mathrm{Fe}$ activity thus produced is carried into the atmosphere during the detonation process. Although ${ }^{55} \mathrm{Fe}$, which has a 2.4 year half-life, decays by electron capture and emits a very weak $5.9 \mathrm{keV} X$-ray, it is of biological interest because iron is an essential nutrient and because a large fraction of the radiation dose from ${ }^{55} \mathrm{Fe}$ is absorbed in the bone marrow, the liver, and the red blood cells. ${ }^{2}$

An early investigation ${ }^{3}$ indicated that the major uptake of ${ }^{55} \mathrm{Fe}$ by humans occurred through food consumption. Those dietary items which contained the greatest concentrations of ${ }^{55} \mathrm{Fe}$ were identified as several seafoods and the meat from certain terrestrial herbivores (caribou and reindeer). Later work ${ }^{4-6}$ determined that the greatest body burdens of ${ }^{55} \mathrm{Fe}$ were found in humans who consumed a large quantity of seafood. Furthermore, the ${ }^{55} \mathrm{Fe}$ body burdens were higher in individuals from mid and northern latitudes than from equatorial latitudes; this is generally consistent with fallout rates. ${ }^{5,7}$

The specific activities of ${ }^{55} \mathrm{Fe}$ in several species of marine organisms, particularly salmon, have been reported to be many times higher than the specific activity of the surface water samples of the oceans. ${ }^{6},{ }^{8}$ Thus, it is apparent that ${ }^{55} \mathrm{Fe}$ and its stable iron counterpart behave significantly different in the marine environment. This difference has manifested itself in 
the transfer of high specific activity ${ }^{5}{ }^{5} \mathrm{Fe}$ to whole population groups who consume large amounts of seafood. These groups include Japanese, Scandinavians, and southeast Alaskan eskimos, all of whom have higher ${ }^{55} \mathrm{Fe}$ burdens than the average of other people in the world. ${ }^{5}, 7$ The strikingly dissimilar marine environmental behavior of ${ }^{55} \mathrm{Fe}$ and stable iron has been observed from the highest trophic level down to the base of the food chain. However, the fundamental reasons for these differences in ${ }^{55} \mathrm{Fe}$ and stable iron behavior have not previously been identified. Since virtually all ${ }^{55} \mathrm{Fe}$ and, in some locations, a substantial fraction of the stable iron enters the ocean as an atmospheric aerosol, a physicochemical characterization of the radio- and stable iron components of atmospheric aerosols was undertaken to determine what fundamenta) differences exist in the chemistries of the iron species. The work reported here includes an investigation of iron and ${ }^{55} \mathrm{Fe}$ in marine aerosols and in sea water relative to ${ }^{55} \mathrm{Fe}$ specific activities and concentrations in the marine food web.

\section{RESEARCH OBJECTIVES}

A major emphasis of this study was to determine the physicochemical nature of ${ }^{55} \mathrm{Fe}$ and stable iron entering the marine environment and use this information to help explain the high specific activity $\left({ }^{5} \mathrm{Fe} / \mathrm{wt} \mathrm{Fe}\right)$ observed in marine organisms. A considerable amount of information describing ${ }^{55} \mathrm{Fe}$ in humans, foodstuffs, and some marine organisms has al ready been reported. ${ }^{3-8}$ The specific objectives of the research presented in this report were to:

1) define the chemical or physical forms of ${ }^{55} \mathrm{Fe}$ and stable iron which enter the northeastern Pacific Ocean;

2) compare the ${ }^{55} \mathrm{Fe}$ specific activities of ocean water (northeastern Pacific surface waters) and ocean aerosols with aerosols collected at the 
adjacent northwest coast of the United States;

3) compare the relative solubility of ${ }^{55} \mathrm{Fe}$ and stable iron in atmospheric aerosols from the northwestern coast of the United States with aerosols from Point Barrow, Alaska;

4) evaluate ${ }^{55} \mathrm{Fe}$ concentrations and specific activities in Pacific Ocean saimon as a function of time, latitude, and species; and

5) determine ${ }^{55} \mathrm{Fe}$ concentrations and specific activity in a variety of marine organisms including members of the food web of pelagic salmon to evaluate differences in specific activities.

\section{EXPERIMENTAL}

Measurement of $55 \mathrm{Fe}$ Concentrations

The only ionizing radiation associated with the decay of ${ }^{55} \mathrm{Fe}$ is the emission of a $5.9 \mathrm{keV} X$-ray. The low energy of this emission requires that the iron content of the sample be. chemically separated from other constituents prior to the ${ }^{55} \mathrm{Fe}$ analysis. All samples of marine organisms were dried and then ashed in a muffle furnace at $450^{\circ} \mathrm{C}$. The residue was then wet ashed with concentrated $\mathrm{HNO}_{3}$ and $\mathrm{HClO}_{4}$, dissolved, and diluted to volume with $\mathrm{HCl}$. The total iron and ${ }^{55} \mathrm{Fe}$ analyses of air filters were performed after the samples had been wet ashed with a mixture of concentrated $\mathrm{HNO}_{3}$ and $\mathrm{HClO}_{4}$. This procedure was shown to dissolve the stable iron in the mineral components of the samples. Aliquots of solutions containing stable iron and ${ }^{55} \mathrm{Fe}$ were extracted into $20 \%$ alamine-366 in xylene, back-extracted into $1 \mathrm{M} \mathrm{HClO}_{4}$, and adjusted to a $\mathrm{pH}$ 8-9 with $\mathrm{NH}_{4} \mathrm{OH}$ to precipitate $\mathrm{Fe}(\mathrm{OH})_{3}$. The precipitate was dissolved with $6 \mathrm{~N} \mathrm{H}_{2} \mathrm{SO}_{4}$ [saturated with $\left(\mathrm{NH}_{4}\right)_{2} \mathrm{C}_{2} \mathrm{O}_{4}$ ] and electrodeposited on to copper planchets. The $5.9 \mathrm{keV} X$-rays emitted during ${ }^{55} \mathrm{Fe}$ decay were counted with a high resolution intrinsic germanium diode (400 $\mathrm{mm}^{2}$ surface area) which 
has a background counting rate of approximately $0.2 \mathrm{cpm}$ in the ${ }^{55} \mathrm{Fe}$ peak region. ${ }^{9}$

Measurement of Stable Iron Concentrations

Stable iron concentrations were determined in the aerosol leaching samples, digested filters, and seawater samples by the method of Collins and Dieh1.10 This technique involves the extraction of an Fe-2,4,6-Tripyridyl-striazine complex into nitrobenzene. This solution is buffered to $\mathrm{pH} 4.4$ and the optical density of the complex in the nitrobenzene solution is measured at 593 nm using a Carey 1605 spectrophotometer.

Stable iron concentrations in the marine organism digestates were determined by the orthophenanthroline method. ${ }^{11}$ At a $\mathrm{pH}$ of 2.2-3.3 ferrous iron is chelated by phenanthroline, forming a colored complex. The optical density is measured at $510 \mathrm{~nm}$.

\section{Aerosol Characterization}

Atmospheric aerosol particulate materials were collected on $0.1 \mathrm{~m}^{2}$ IPC filters using linear flow rates of $\sim 30 \mathrm{~m} / \mathrm{sec}$ with a high volume pumping system located at Quillayute, Washington ( $46^{\circ}$ north latitude); the total volume of air passed through each filter was $1.5-2.0 \times 10^{4} \mathrm{~m}^{3}$. This 1ocation is situated on the western side of the 0lympic Mountains $4 \mathrm{~km}$ from the seacoast and, under proper meteorological conditions, receives air moving inland on a transpacific trajectory. ${ }^{12}$ Under these conditions, the aerosol samples represent essentially a marine aerosol. Large volume aerosol samples were also collected at Point Barrow, Alaska ( $71^{\circ}$ north Tatitude).

These clean aerosol samples were subjected to sequential leachings, first with sea water, and then with a chemical solution. This served to simulate the release of ${ }^{55} \mathrm{Fe}$ and stable iron from atmospheric aerosol particles during 
initial leaching with sea water, and also to characterize the chemical and physical forms of the aerosol iron species. For these analyses, the aerosol samples were placed in a glass column and contacted under quiescent conditions for $24 \mathrm{hr}$ with a sample of sea water which had previously been filtered through a $0.45 \mu$ filter. The seawater sample was removed, filtered through a $0.45 \mu$ filter, acidified to a $\mathrm{pH}$ of 1-2 with $\mathrm{HCl}$ and stored in a polyethylene bottle prior to analysis. The aerosol remaining on the filter was then contacted with either $0.5 \% \mathrm{NH}_{2} \mathrm{OH} \cdot \mathrm{HCl}$ or $0.001 \mathrm{~N} \mathrm{HNO}_{3}-\mathrm{H}_{2} \mathrm{SO}_{4}$ for $4 \mathrm{hr}$. After the leaching period, the leachate was filtered through a $0.45 \mu$ filter and stored in a polyethylene bottle prior to analysis. The remaining aerosol particulate matter was wet ashed with a mixture of concentrated $\mathrm{HNO}_{3}$ and $\mathrm{HClO}_{4}$. Each of the samples was analyzed for ${ }^{55} \mathrm{Fe}$ and stable iron.

Collection of Seawater Samples for Stable and Radio-Iron Determination

Several surface water samples were collected in the northeast Pacific Ocean along the coast of British Columbia and into the Gulf of Alaska (see Figure 4). Samples for measurement of stable iron were collected with a plastic bucket from the bow to avoid contamination by the ship. The samples were stored in precleaned polyethylene bottles and acidified to $\mathrm{pH} 1-2$. These seawater samples were subsequently analyzed for the total iron solubilized under the acid storage conditions. Samples for the measurement of ${ }^{55} \mathrm{Fe}$ were collected by use of a Battelle large volume water sampler. ${ }^{13}$ These large volume water samples consisted of a particulate fraction collected on glass fiber filters and a "dissolved" fraction collected on $\mathrm{Al}_{2} \mathrm{O}_{3}$ beds. The filters were wet ashed with a mixture of concentrated $\mathrm{HNO}_{3}$ and $\mathrm{HClO}_{4}$. The ${ }^{55} \mathrm{Fe}$ was removed from the $\mathrm{Al}_{2} \mathrm{O}_{3}$ by leaching with aqua regia. The resulting solutions were analyzed for ${ }^{55} \mathrm{Fe}$. 
Collection of Marine Organisms

Salmon specimens were collected along the west coast of the contiguous United States and the western coast of Alaska. These included mature fish from five North American species caught as they began their spawning run. In addition, some immature salmon were also collected near the mouth of the Columbia River to provide a basis for comparison. Two collections of marine organisms which comprise the food web of which salmon are a part were also made. Samples of phytoplankton, crustacea, small fish, and benthic organisms have been collected off the Washington and Oregon coasts (Figures 8 and 9).

\section{RESULTS AND DISCUSSIONS}

Iron-55 and Stable Iron in Oceanic Aerosols

Essentially all of the ${ }^{55} \mathrm{Fe}$ entering the oceans is derived from atmospheric input and this may be true for stable iron as well in some ocean areas. On the other hand, riverine discharge is the principal source of stable iron to the ocean. ${ }^{24}$ However, this discharge from continental rivers has its major impact in equatorial regions. Ice cap melt, a second major source, has $i$ ts effect mainly in the Antarctic. Thus, these two major stable iron sources are at continental boundaries and are specific for given regions of the globe. Because continental run-off and polar ice cap melting supply stable iron at the ocean edge mainly in a particulate form which may be subject to rapid deposition, it is probable that atmospheric transport of stable iron provides a major impact on open ocean areas at mid-and more northerly latitudes of the northern hemisphere. The atmospheric source is certainly significant for iron from anthropogenic inputs (generally centered in the mid-latitudes) which are principally from fossil fuel combustion and steel production. These two industries supply more than one-third of the total of all stable iron input to 
the atmosphere. ${ }^{14}$ Thus, atmospheric aerosols which are the sole transport vector for the input of radio-iron to the oceans are also the most significant transport vector for stable iron which has entered the atmosphere due to man's activities. Because of the significance of the input of ${ }^{55} \mathrm{Fe}$ to the ocean through this transport vector (especially at the mid-latitudes), it was desired to characterize the chemical forms of both radio- and stable iron on atmospheric aerosols and to simulate in the laboratory the release of ${ }^{55} \mathrm{Fe}$ and stable iron from atmospheric aerosol particles upon contact with sea water.

The two-step leaching procedure previously described was used to estimate the initial release of iron into sea water and to remove hydrous iron oxides and surface-associated iron species from the aerosol particles. Since the major portion of iron in atmospheric aerosols is in a geological matrix, having originated from aeolian transport of terrestrial dust, our leaching technique was tested to evaluate the stable iron leaching from natural minerals. Four crystalline iron minerals--pyrite $\left(\mathrm{FeS}_{2}\right)$, limonite $\left(\mathrm{FeO} \cdot \mathrm{OH} \cdot \mathrm{nH}_{2} \mathrm{O}\right)$, hematite $\left(\mathrm{Fe}_{2} \mathrm{O}_{3}\right)$, and magnetite $\left(\mathrm{FeO} \cdot \mathrm{Fe}_{2} \mathrm{O}_{3}\right)$--were ground to $<200$ mesh, treated with sea water for a period of $24 \mathrm{hr}$, then treated for $4 \mathrm{hr}$ with $0.5 \% \mathrm{NH}_{2} \mathrm{OH} \cdot \mathrm{HCl}$. [The $0.5 \%$ hydroxylamine hydrochloride, a weak reducing agent, readily dissolves amorphous iron oxides. ${ }^{15}$ ] The results of this initial seawater and chemical leaching solution study are shown in Table 1. In this investigation, each of these four minerals was virtually unaffected by the contact with sea water. Only a very small percentage, less than $1 \%$, of each mineral was dissolved by treatment with the hydroxylamine hydrochloride, and this may have been due mostly to higher leaching rates from surfaces newly formed during grinding of the test materials.

Al though only a very small fraction of iron was released from each of these minerals by the chemical treatments, there was evidence of some dissolution 
of the magnetite. To evaluate the relationship between dissolution and leaching solution concentration, several different leachant concentrations were tested with additional magnetite samples. In addition to a range of $\mathrm{NH}_{2} \mathrm{OH} \cdot \mathrm{HCl}$

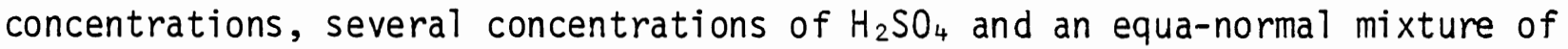
$\mathrm{H}_{2} \mathrm{SO}_{4}$ and $\mathrm{HNO}_{3}$ were evaluated. The dilute acid solutions were evaluated since both $\mathrm{H}_{2} \mathrm{SO}_{4}$ and $\mathrm{HNO}_{3}$ may be formed in the atmosphere downwind from heavily industrialized areas and may lead to acid rainfall conditions with $\mathrm{pH}^{\prime} \mathrm{s}$ in the neighborhood of 2.0-5.0.16 The results of this study are shown in Figure 1 . The general trend indicated is an increasing percent iron dissolution with increasing concentration of the leaching solution. On the basis of these data, the final chemical solutions used for leaching were $0.5 \% \mathrm{NH}_{2} \mathrm{OH} \cdot \mathrm{HCl}$ and $10^{-3}$ $\mathrm{N} \mathrm{H}_{2} \mathrm{SO}_{4}-\mathrm{HNO}_{3}$. (This latter solution would approximate the $\mathrm{pH}$ of a typical acid rain.) Neither of these two solutions dissolves a significant amount of the iron present in the crystalline minerals. Thus, these chemical leachants have very little effect on aeolian dust present in atmospheric aerosol samples.

The high volume clean aerosol samples collected at Quillayute, Washington, and Point Barrow, Alaska, were also leached by the sea water and chemical solution method. The ${ }^{55} \mathrm{Fe}$ in five Quillayute aerosol samples was much more readily removed than was the stable iron, as evidenced by ${ }^{5} \mathrm{Fe}$ specific activities in the leachates and the total sample (see Figure 2). The specific activities of the seawater leaches were 1.2-30 times greater than those of their corresponding filters. The chemical leachate specific activities were 2.2-65 times greater than the total filter specific activities. Up to $30 \%$ of the total ${ }^{55} \mathrm{Fe}$ present on these Quillayute aerosol sampies was released into the seawater and chemical leaching solutions. This compares to a maximum of $5.7 \%$ of the total stable iron released by these treatments. Thus, one would predict from these data that a much larger proportion of ${ }^{55} \mathrm{Fe}$ than stable iron would be 
released from aerosol particles shortly after contact by surface ocean water or in an acidic gut after ingestion by marine biota.

The leaching of two air filters from Point Barrow, Alaska, $77^{\circ}$ North, was even more effective in removing ${ }^{55} \mathrm{Fe}$ vs. Stable iron (Figure 3 ). The ${ }^{55} \mathrm{Fe}$ specific activities in the sea water were 4-19 times greater than on the original filters. From $67-97 \%$ of the total ${ }^{55} \mathrm{Fe}$ on these filters was solubilized during the $24 \mathrm{hr}$ contact with sea water, with little additional release into the chemical leachant. This behavior indicates an even more rapid release of high specific activity ${ }^{55} \mathrm{Fe}$ when these atmospheric aerosols contact ocean surfaces or are ingested by marine biota.

The comparatively high solubility of ${ }^{55} \mathrm{Fe}$ suggests that a large proportion is associated with the surface of the aerosol particles and that it is likely an amorphous iron oxide or very small particulate species attached to the surfaces of the larger aerosol particles. These forms are easily dissolved by sea water, by $\mathrm{NH}_{2} \mathrm{OH} \cdot \mathrm{HCl}$, and by dilute acids, while more crystalline iron forms are not.

A comparison of the ieaching behavior of the ${ }^{55} \mathrm{Fe}$ species associated with the Point Barrow and Quillayute aerosols indicates that in both cases a significant proportion of the total ${ }^{55} \mathrm{Fe}$ is released. The higher specific activities and larger fractions of ${ }^{55} \mathrm{Fe}$ released from the Point Barrow filters suggest some differences in the nature of the ${ }^{55} \mathrm{Fe}$ associated with the aerosols from these two locations. The higher specific activity of ${ }^{5} \mathrm{Fe}$ on the Point Barrow filters that is leached in comparison to the Quillayute filters is apparently due to a much larger fraction of anthropogenic iron in mid-latitude aerosols. It is likely that the larger proportion of stable iron leached from the Quillayute samples is surface-associated stable iron that has been introduced into 
the atmosphere from anthropogenic sources and has condensed or attached onto the surface of the larger particulate materials in the form of amorphous oxides or very small particles.

The data from these leaching investigations clearly indicate differences between the physical/chemical forms of ${ }^{55} \mathrm{Fe}$ and stable iron species in atmospheric aerosols. These differences in forms help explain preferential marine organism uptake of ${ }^{55} \mathrm{Fe}$ relative to stable iron. Since marine organisms incorporate soluble forms of elements and since ${ }^{55} \mathrm{Fe}$ is more readily solubilized than the stable iron in atmospheric aerosols, this soluble ${ }^{55} \mathrm{Fe}$ is more bioavailable than the nonsolubilized stable iron on the aerosols. There is evidence that much of the stable iron already present in marine water exists in a form unavailable for biological utilization; ${ }^{17}$ thus, this stable iron already in the oceans does not effectively dilute the input of available ${ }^{55} \mathrm{Fe}$. Iron-55 input to the oceans at mid-latitudes, while receiving little dilution from stable iron forms al ready present in sea water, may be partially diluted by a portion of the anthropogenic iron associated with these mid-latitude aerosols. Such dilution is not as significant for ${ }^{55} \mathrm{Fe}$ deposition at more northern latitudes.

Seawater Samples

Surface water samples were collected in the northeast Pacific Ocean off the coast of British Columbia and into the Gulf of Alaska. The purpose of this collection was to compare the ${ }^{55} \mathrm{Fe}$ specific activities in the seawater samples in early and late summer with the specific activities of atmospheric aerosol samples during the annual early summer fallout maximum.

The ${ }^{55} \mathrm{Fe}$ specific activities and the sampling locations for seawater samples collected during May and August, 1974, are given in Figure 4. The May sampling corresponds approximately to the annual maximum in atmospheric failout. 
The seawater specific activity at this time ranged from $9.7-39 \mathrm{dpm}{ }^{55} \mathrm{Fe} / \mathrm{mg} \mathrm{Fe}$ and averaged approximately $21 \mathrm{dpm}{ }^{55} \mathrm{Fe} / \mathrm{mg} \mathrm{Fe}$. This average value compares favorably to the average specific activity of atmospheric aerosols collected at Quillayute, Washington (approximately $22 \mathrm{dpm}{ }^{55} \mathrm{Fe} / \mathrm{mg} \mathrm{Fe}$ ) during May, 1974. These data suggested that atmospheric aerosol input could account for all of the iron entering the north Pacific waters and imply a very short residence time for both stable iron and ${ }^{5} \mathrm{Fe}$.

The values of the specific activities of the surface water samples collected during Tate August, 1974, are also given in Figure 4. These values are substantially different, ranging from $1.2-12 \mathrm{dpm}{ }^{5} \mathrm{Fe} / \mathrm{mg} \mathrm{Fe}$ and averaging $4.8 \mathrm{dpm}{ }^{55} \mathrm{Fe} / \mathrm{mg} \mathrm{Fe}$, approximately $23 \%$ of the May value. This decrease is associated with both a decrease in ${ }^{55} \mathrm{Fe}$ content in the surface water samples and an apparent increase in stable iron (see Table 2). Because of the wide variation in ${ }^{55} \mathrm{Fe}$ specific activity between samples collected within each time interval, the significance of the differences in these two averages is questionable. However, these data do further suggest widely variable concentrations and short residence times for iron in the ocean.

Further evidence for a short residence time is implied when one considers that this portion of the northeast Pacific Ocean is a relatively isolated water mass fed predominantly by the Subarctic Current. ${ }^{18}$ Approximately onehalf of the total water mass in this Gulf of Alaska region enters the Gulf of Alaska gyre and is recirculated. ${ }^{19}$ Therefore, there is relatively 1 ittle "new" water advected into this region during any three-month period, such as from the May to August sampling of 1974. Major changes in surface water specific activities thus require relatively rapid removal of iron. This rapid removal of ${ }^{55} \mathrm{Fe}$ from the Gulf of Alaska surface waters is in harmony with other 
estimates of change in concentration of ${ }^{55} \mathrm{Fe}$ in surface water of the northeast Pacific. Based on changes in the ${ }^{55} \mathrm{Fe}$ concentrations in salmon, the ${ }^{55} \mathrm{Fe}$ in these surface waters decreased with a half time of 11.5 months following the 1961-1962 US-USSR test series. ${ }^{20}$ This is nearly exactly the rate of decrease of deposition on the earth's surface from the stratospheric reservoir, ${ }^{21}$ and thus indicates a very short residence time for ${ }^{55} \mathrm{Fe}$ in ocean surface waters. It has recently been reported that ${ }^{55} \mathrm{Fe}$ associated with particulate materials in the Atlantic Ocean settles very rapidly out of the entire water column. ${ }^{22}$ All of these facts indicate that the flux of ${ }^{55} \mathrm{Fe}$ through the photic zone of the oceans is quite rapid.

Marine Organisms

Some of the highest concentrations of ${ }^{55} \mathrm{Fe}$ and the greatest ${ }^{55} \mathrm{Fe}$ specific activities found in the marine environment have been reported for the salmon populations. ${ }^{3-6,8,20}$ We have sampled individuals from five salmon species along the west coast of the contiguous United States and the coast of Alaska over a period of years to observe the concentrations and specific activities as a function of time of collection, species, and age of the salmon.

Figure 5 is a comparison of ${ }^{55} \mathrm{Fe}$ specific activities in several mature species of salmon collected at Cook Inlet in Alaska. The average specific activities for these four salmon species--pink, sockeye, chum, coho--vary by less than a factor of 2 . The relatively small difference in the specific activities that is shown for these four salmon species allows comparison of data from several different species, with only minor corrections for species variability being necessary.

The sampling of salmon populations as a function of time has allowed the relationship between input rate and the ${ }^{55} \mathrm{Fe}$ concentrations in salmon to be established. The data in Figure 6 show the decline of the ${ }^{55} \mathrm{Fe}$ concentrations 
in several species of Pacific saimon during the years 1965 to 1972 . The halftimes of the slopes of the lines of decreasing ${ }^{55} \mathrm{Fe}$ concentrations are similar and average approximately 10 months. This half-time is comparable to the 11.8 month residence time of stratospheric debris. ${ }^{21}$ The decrease in salmon ${ }^{55} \mathrm{Fe}$ concentrations with time parallels the decrease in the input rate of ${ }^{55} \mathrm{Fe}$ from the upper atmosphere. In addition, the nearly parallel nature of these curves suggests that the input rates of ${ }^{55} \mathrm{Fe}$ into the migration areas of the three groups of salmon have been relatively constant. (The change in the rate of decrease that was experienced in the early 1970's was due to fallout input from more recent Chinese nuclear tests. This fallout increased the ${ }^{55} \mathrm{Fe}$ concentrations in some of the species sampled from the southern Alaska area.) These data, together with the estimated ${ }^{55} \mathrm{Fe}$ half-times in the upper $100 \mathrm{~m}$ of the Pacific 0 cean ${ }^{20}$ suggest that the ${ }^{55} \mathrm{Fe}$ concentrations in salmon simply reflect the ${ }^{55} \mathrm{Fe}$ concentrations in sea water which, in turn, are controlled by the half-time of ${ }^{55} \mathrm{Fe}$ residence in the stratosphere. This implies that the ${ }^{55} \mathrm{Fe}$ input to the oceans is biologically available for only a short period of time and when once removed from the pool is not recycled to any great extent.

Figure 6 also shows that the highest concentration of ${ }^{55} \mathrm{Fe}$ is found in the second run of salmon to Kotzebue, a coastal town in the northwest portion of Alaska. The lowest ${ }^{55} \mathrm{Fe}$ concentrations shown on this curve are from salmon collected off the Washington Coast, and intermediate ${ }^{55} \mathrm{Fe}$ concentrations 
are seen for the first run of Kotzebue salmon and for salmon in the Cook Inlet area in southern Alaska (Kenai-Bristol Bay). These data indicate that ${ }^{55} \mathrm{Fe}$ concentrations in Pacific salmon increase in more northerly latitudes. Figure 7 is a diagram of the variations in ${ }^{55} \mathrm{Fe}$ specific activity in Pacific salmon during the year 1968 as a function of latitude. The data for the five species of salmon represented here show dramatically the increase of ${ }^{55} \mathrm{Fe}$ specific activity by a factor of from 10 to 30 from approximately $38^{\circ}$ North latitude to $68^{\circ}$ North latitude. These specific activities show a progressive increase from the mid-California area through northern washington and an additional increase in one of the salmon runs from Kotzebue, Alaska, at $68^{\circ}$ North latitude.

The concentrations of fallout isotopes observed at Richland, Washington, $46^{\circ}$ North latitude, are approximately twice the concentrations seen at Point Barrow, Alaska, $71^{\circ}$ North. 21 Thus, salmon which live in the mid-latitudes of $45^{\circ}$ to $55^{\circ}$ are exposed to greater total ${ }^{55} \mathrm{Fe}$ concentrations than are those salmon which live north of the Arctic Circle. Nevertheless, it is the more northerly salmon that have the higher ${ }^{55} \mathrm{Fe}$ specific activities. This is due to the fact that there is very little stable iron in atmospheric aerosols at $71^{\circ}$ North latitude to dilute the radio-iron. The data presented in Figures 2 and 3 show that the specific activity of atmospheric aerosols entering the ocean is greater in the more northerly latitudes than on the atmospheric aerosols in the mid-latitude regions. In addition, we demonstrated that the specific activity of iron which is solubilized upon contact of atmospheric aerosols with sea water is much greater for aerosols from $71^{\circ}$ North latitude than for those from $46^{\circ}$ North latitude. The greatest proportion of this iron on the mid-latitude aerosol particulate materials is of geologic nature and apparently due to resuspended terrestrial dust; however, 
there is also a portion of this stable iron that is biologically available upon entering the ocean. This is likely iron from some anthropogenic sources such as that which enters the atmosphere from stee 1 mills and fossil fuel plants. This iron apparently dilutes the ${ }^{55} \mathrm{Fe}$ specific activities in organisms living in the mid-latitudes.

To help evaluate the ${ }^{55} \mathrm{Fe}$ distribution patterns throughout the marine food web, samplings of marine organisms were conducted in 1968 and 1971 off the coasts of Washington and Oregon and in the Columbia River estuary. The sampling locations for each of these organism collections are shown in Figures 8 and 9. A summary of the data from these collections is presented in Table 3. Average values for, the ${ }^{55} \mathrm{Fe}$ specific activities of salmon from the Columbia River runs for each of these two years are also listed in Table 3. The highest ${ }^{55} \mathrm{Fe}$ specific activities are seen for those organisms which are surface-dwelling organisms. Some predatory fish such as the sea bass and the rosy rock fish also show very high ${ }^{55} \mathrm{Fe}$ specific activities. Unfortunately, these data only give a partial indication of food chain relationships which bear on the specific activity of ${ }^{55} \mathrm{Fe}$ in marine organisms. It is clear that the specific activity in salmon and other predators is high compared to that in atmospheric aerosols and sea water. Most of the remaining organisms have specific activities which are considerably less than those of the salmon and other mid-water or near-surface predators. Although these observations may be the result of a number of factors, there appears to be a simple explanation. The ${ }^{55} \mathrm{Fe}$ entering the ocean from the atmospheric aerosols is available for biological incorporation from surface waters for only a short period of time. Therefore, those organisms living and feeding near the surface of the ocean would have access to the freshly deposited ${ }^{55} \mathrm{Fe}$ and could, therefore, accumulate the "available" ${ }^{55} \mathrm{Fe}$. 


\section{SUMMARY}

Aerosol characterization investigations indicate that the greater biological availability of ${ }^{55} \mathrm{Fe}$ in the marine environment is due to the difference in physicochemical properties of radio- and stable iron which enter the ocean on atmospheric aerosols. The ${ }^{55} \mathrm{Fe}$ appears to have condensed or attached itself on the aerosol surfaces as an amorphous iron oxide or as very small particles while the major proportion of the stable iron is an integral part of the mineral matrix in these aerosols. This ${ }^{55} \mathrm{Fe}$ is easily solubilized upon contact with sea water and other solutions. A small portion of the aerosol stable iron content is also surface associated and solubilizable. This portion of total iron is larger for aerosols from mid-latitudes than for aerosols from more northern latitudes. It appears that this more soluble stable iron is from anthropogenic sources since it is present in greater abundance at mid-latitudes. Laboratory investigations indicate that ${ }^{55} \mathrm{Fe}$ is released more readily than the stable iron upon contact with sea water and chemical leaching solutions. It is expected that the same response occurs as atmospheric aerosols enter and are leached by the surface waters of the ocean.

The relatively rapid changes in ${ }^{55} \mathrm{Fe}$ and stable iron in open-ocean surface waters indicate a short residence time for iron and that atmospheric aerosols probably are the major source of both radio- and stable iron to some oceanic water masses. These data, together with evidence that the half-time for ${ }^{55} \mathrm{Fe}$ in organisms (salmon) from the top of the marine food web is approximately the same as the stratospheric residence half-time for fallout radionuclides, suggest that fallout ${ }^{55} \mathrm{Fe}$ has a very short residence time in the surface layer of the ocean and is thus biologically available to most marine organisms for only a short time. 
The specific activities of ${ }^{55} \mathrm{Fe}$ in ocean organisms is not correlated with hemispheric ${ }^{55} \mathrm{Fe}$ fallout but is a function of actual stable iron dilution. This dilution effect is greater at mid-latitudes $\left(46^{\circ}\right.$ North) than at more northerly latitudes $\left(70^{\circ}\right.$ North). This phenomenon is apparently related to the substantially greater biological availability of anthropogenic iron over geologic iron.

The comparison of the biogeochemistry of ${ }^{55} \mathrm{Fe}$ and stable iron in atmospheric aerosols, surface ocean waters, and marine organisms has demonstrated that there are significant differences in the environmental behaviors and food chain uptake of these iron isotopes. These differences are related to their different physical/chemical form and have manifested themselves in enhanced uptake by marine organisms. It is, therefore, evident that one cannot depend on dilution of an element or one of its isotopes which are from anthropogenic sources by a large terrestrial or marine reservoir of the stable element unless their forms are identical. A knowledge of the chemical and physical forms of the element both in the reservoir and in the input source are necessary to evaluate the potential effect of these anthropogenic increases. 


\section{REFERENCES}

1. Thomas, C. W. and J. C. Langford. 1972. Air Concentrations of ${ }^{9}{ }^{\circ} \mathrm{Sr}$ and

${ }^{5} \mathrm{Fe}$ at Richland, Washington from 1963 to 1970, pp. 104-106. In: Pacific Northwest Laboratory Annual Report for 1971. BNWL-1651, Pt. 1, BattelleNorthwest, Richland, Washington.

2. Wrenn, M. E. and N. Cohen. 1967. Iron-55 from Nuclear Fallout in the Blood of Adults: Dosimetric Implications and Development of a Model to Predict Levels in Blood. Health Physics 13, 1075-1082.

3. Palmer, H. E. and T. M. Beasley. 1965. Iron-55 in Humans and Their Foods. Science 149, 431-432.

4. Palmer, H. E., T. M. Beasley and T. R. Folsom. 1966. Iron-55 in Marine Environment and in People Who Eat Ocean Fish. Nature 21, 1253-1254.

5. Palmer, H. E. and T. M. Beasley. 1967. Iron-55 in Man and the Biosphere. Heal th Physics 13, 889-895.

6. Palmer, H. E., J. C. Langford, C. E. Jenkins, T. M. Beasley and J. M. Aase. 1968. Levels of Iron-55 in Humans, Animals, and Food, 1964-1967. Radiological Health Data and Reports 9 , 387-390.

7. Langford, J. C. and C. E. Jenkins. 1971. The Latitudinal Variations of ${ }^{5} \mathrm{Fe}$ in Man and Cattle. Health Physics 21, 71-77.

8. Jenkins, C. E. and J. C. Langford. $1974 .{ }^{55} \mathrm{Fe}$ Concentrations and Specific Activities in North Pacific Marine Organisms. IEEE Transactions on Nuclear Science NS-21, 517-521.

9. Weimer, W. C. and J. C. Langford. 1976. Physical-Chemical Characterization of ${ }^{55} \mathrm{Fe}$ and Stable Fe Forms in Seawater and Oceanic Aerosols, pp. 158-159. In: Pacific Northwest Laboratory Annual Report for 1975. BNWL-2000, Pt. 2, Battelle-Northwest, Richland, Washington.

10. Collins, P. F. and H. Diehl. 1960. Tripyridyltriazine, A Reagent for the Determinatio of Iron in Sea Water. J. Marine Research 18, 152-156.

11. Sande11, E. B. 1959. Colorimetric Determination of Traces of Metals, 3rd Ed. Interscience Pub., New York, New York. $1032 \mathrm{p}$.

12. Fox, T. D. and J. D. Ludwick. 1976. Lead Concentration Associated with $1000 \mathrm{mb}$ Geostrophic Back Trajectories at Quillayute, Washington. Atmospheric Environment 10, 799-803.

13. Silker, W. B., R. W. Perkins and H. G. Rieck. 1971. A Sampler for Concentrating Radionuclides from Natural Waters. Ocean Eng. 2, 49-55.

14. National Academy of Sciences Study Pane1. 1975. Assessing Potential Ocean Pollutants. National Academy of Sciences, Washington, D.C. 438 p. 
15. Chester, R. and M. J. Hughes. 1967. A Chemical Technique for the Separation of Ferro-manganese Minerals, Carbonate Minerals, and Adsorbed Trace Elements from Pelagic Sediments. Chemical Geology 2 , 249-262.

16. Likens, G. E. and F. H. Bormann. 1974. Acid Rain: A Serious Regional Environmental Problem. Science 184, 1176-1179.

17. Lewin, J. and C. H. Chen. 1971. Available Iron: A Limiting Factor for Marine Phytoplankton. Limnol. Oceanog. 16, 670-675.

18. Dodimead, A. J., F. Favorite, and T. Hirano. 1963. Salmon of the North Pacific Ocean--Part II. Review of Oceanography of the Subarctic Pacific Region. Int. N. Pac. Fish. Comm. Bul1. 13, Vancouver, Canada, 195 p.

19. Favorite, F., A. J. Dodimead, and K. Nasu. 1976. Oceanography of the Subarctic Pacific Region, 1960-71. Int. N. Pac. Fish. Comm. Bull. 33. Vancouver, Canada. $187 \mathrm{p}$.

20. Jennings, C. D. and C. L. Osterberg. 1971. Specific Activity of Iron-55 in Salmon, pp. 703-708. In: Proc. Third Nat. Symp. on Radioecology. May 10-12. Oak Ridge, Tenn. 1268 p.

21. Thomas, C. W., J. A. Young, N. A. Wogman and R. W. Perkins. 1970. The Measurement and Behavior of Airborne Radionucl ides Since 1962, pp. 158172. In: Radionuclides in the Environment. Advances in Chemistry Series Number 93, American Chemical Society, Washington, D. C. 438 p.

22. Labeyrie, L. D., H. D. Livingston and V. T. Bowen. 1976. Comparison of the Distributions in Marine Sediments of the Fallout Derived Nuclides ${ }^{55} \mathrm{Fe}$ and $239,240 \mathrm{Pu}$ : A New Approach to the Chemistry of Envi ronmental Radionuclides, pp. 121-137. In: Transuranium Nucl ides in the Environment. International Atomic Energy Agency, Vienna. 724 p. 
TABLE 1. Chemical Dissolution of Fe-Containing Minerals

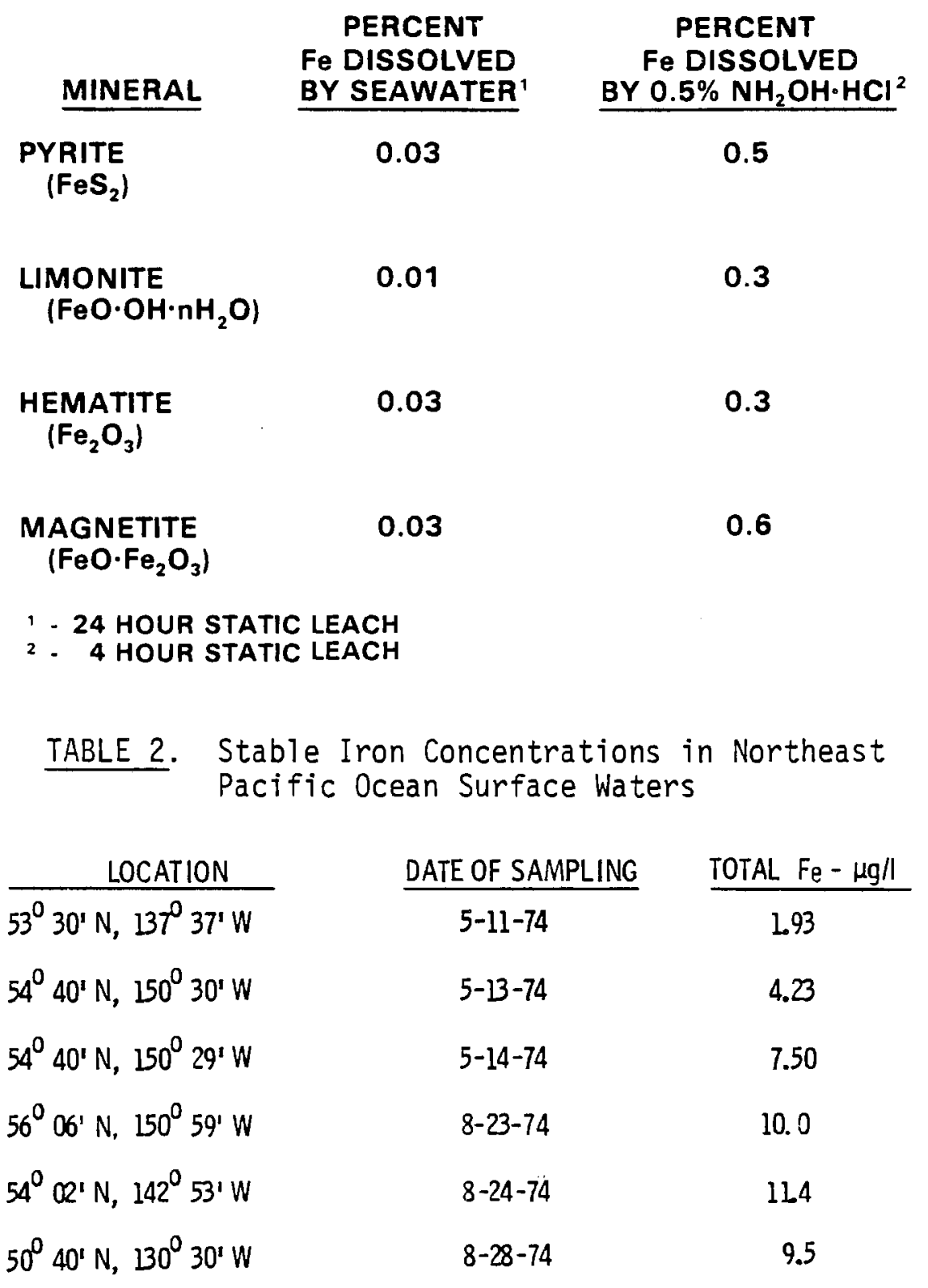


TABLE 3. ${ }^{55} \mathrm{Fe}$ Specific Activities in Air, Seawater and Marine and Estuarine Organisms

\begin{tabular}{|c|c|c|c|}
\hline YEAR & STATION & SAMPLE & $\Phi \mathrm{m} / \mathrm{mg} \mathrm{Fe}$ \\
\hline \multirow[t]{24}{*}{1968} & $33 \mathrm{~A}$ & SCULPIN & 9.8 \\
\hline & $33 \mathrm{~A}$ & LONGFINNED SMELT & 11 \\
\hline & 5 & SMELT & 21 \\
\hline & 5 & SHINER PERCH & 13 \\
\hline & 5 & SAND SOLE & 4.1 \\
\hline & 35 & PEA MOUTH CHUB & 14 \\
\hline & 4 & SEA BASS & 105 \\
\hline & 4 & TOM COD & 4.6 \\
\hline & 4 & SAND SOLE & 3.4 \\
\hline & 4 & DUNGENESS CRAB & 3.0 \\
\hline & 4 & DUNGENESS CRAB & 63 \\
\hline & 4 & SHINER PERCH & 13 \\
\hline & 19 & ROSY ROCK FISH & 1808 \\
\hline & 19 & SAND SOLE & 47 \\
\hline & 19 & LEMON SOLE & 20 \\
\hline & 19 & REX SOLE & 3.5 \\
\hline & 19 & DOVER SOLE & 3.8 \\
\hline & 19 & DUNGENESS CRAB & 3.8 \\
\hline & $\left.\begin{array}{r}44^{\circ} 35^{\prime} \mathrm{N} \\
124^{\circ} 45^{\prime} \mathrm{W}\end{array}\right\}$ & VALELA VALELLA & 260 \\
\hline & $\left.44^{0} 381 \mathrm{~N}\right\}$ & EUPHAUSIDS & 15 \\
\hline & $132^{\circ} 29^{\prime} W J$ & & \\
\hline & COLUMBIA RIVER & KING SALMON (MUSCLE TISSUE) & 278 \\
\hline & $\left.\begin{array}{l}300 \text { MILES OFF } \\
\text { NEWPORT, OREGON }\end{array}\right\}$ & SEAWATER (SURFACE) & 17 \\
\hline & RICHLAND, WASHINGTON & AIR FILTER (YEARLY AVERAGE) & 126 \\
\hline \multirow[t]{18}{*}{1971} & 20 & REX SOLE & 0.63 \\
\hline & 20 & PINK SHRIMP & 0.60 \\
\hline & 27 & HOLOTHURIAN & 1.2 \\
\hline & 27 & PINK SHRIMP & 13 \\
\hline & 29 & PINK SHRIMP & 0.9 \\
\hline & 30 & LEMON SOLE & 27.4 \\
\hline & 30 & SMELT (ANCHOVY) & 6.6 \\
\hline & 35 & LEMON SOLE (SMALL) & 038 \\
\hline & 35 & LEMON SOLE (LARGE) & 1.1 \\
\hline & 35 & LEMON SOLE & 10 \\
\hline & 37 & ROUGH SCALE RAT TAIL & 14 \\
\hline & 41 & EUPHAUSID & 326 \\
\hline & 41 & EUPHAUSID & 217 \\
\hline & 42 & EUPHAUSID & 187 \\
\hline & 43 & LANTERN FISH & 421 \\
\hline & 44 & SEAWATER (SURFACE) & 0.51 \\
\hline & COLUMBIA RIVER & KING SALMON (MUSCLE TISSUE) & 24.1 \\
\hline & RICHLAND, WASHINGTON & AIR FILTER (YEARLY AVERAGE) & 3.9 \\
\hline
\end{tabular}




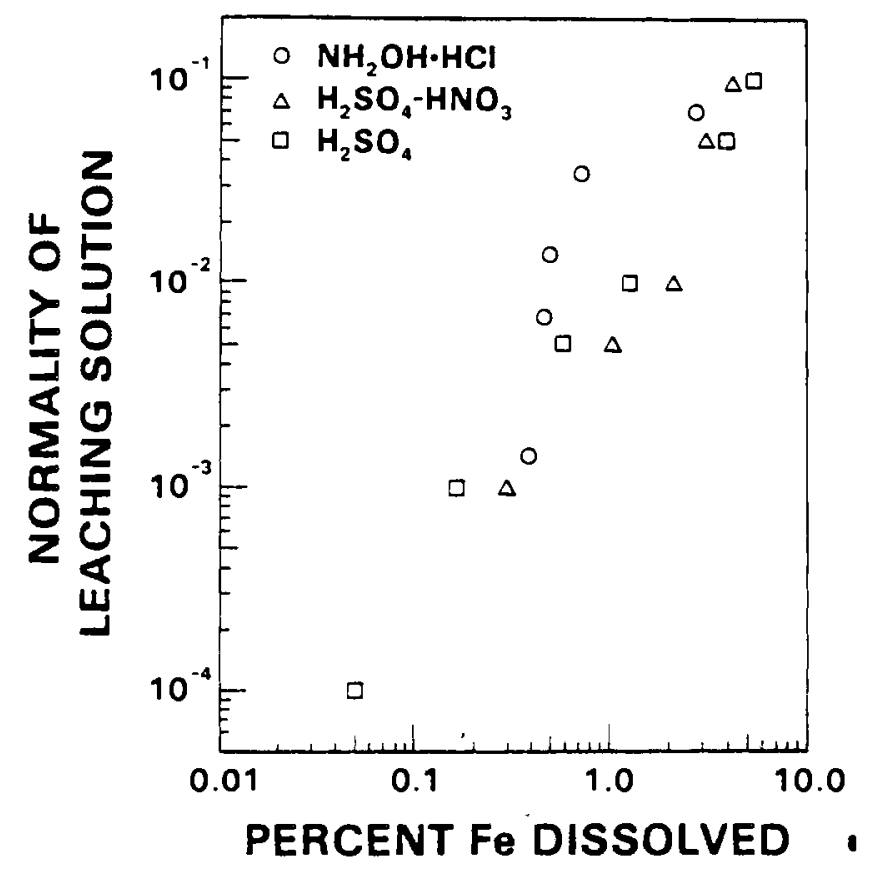

FIGURE 1. Effect of Leaching Solution Concentration on Magnetite Dissolution

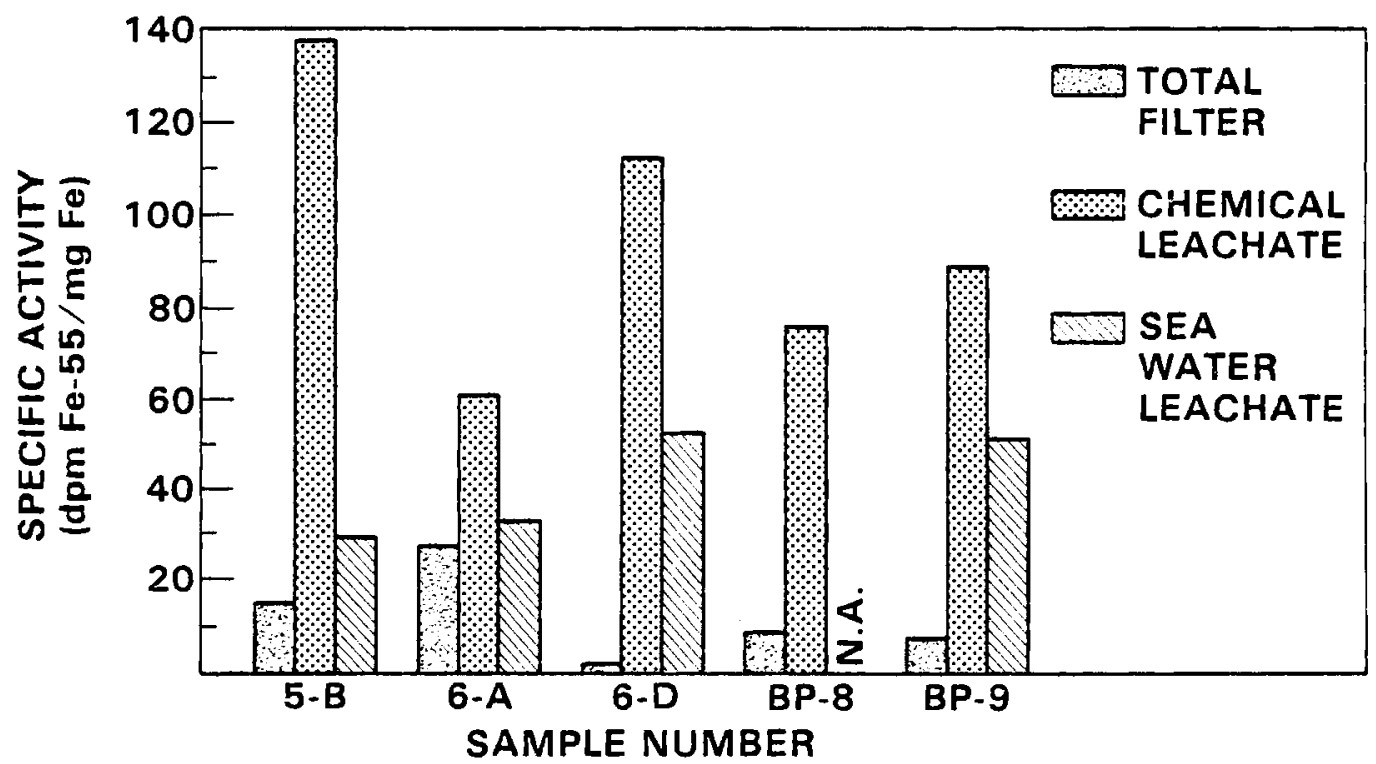

FIGURE 2. ${ }^{55}$ Fe Specific Activities in Quillayute Aerosols and Aerosol Leachates (1974) 


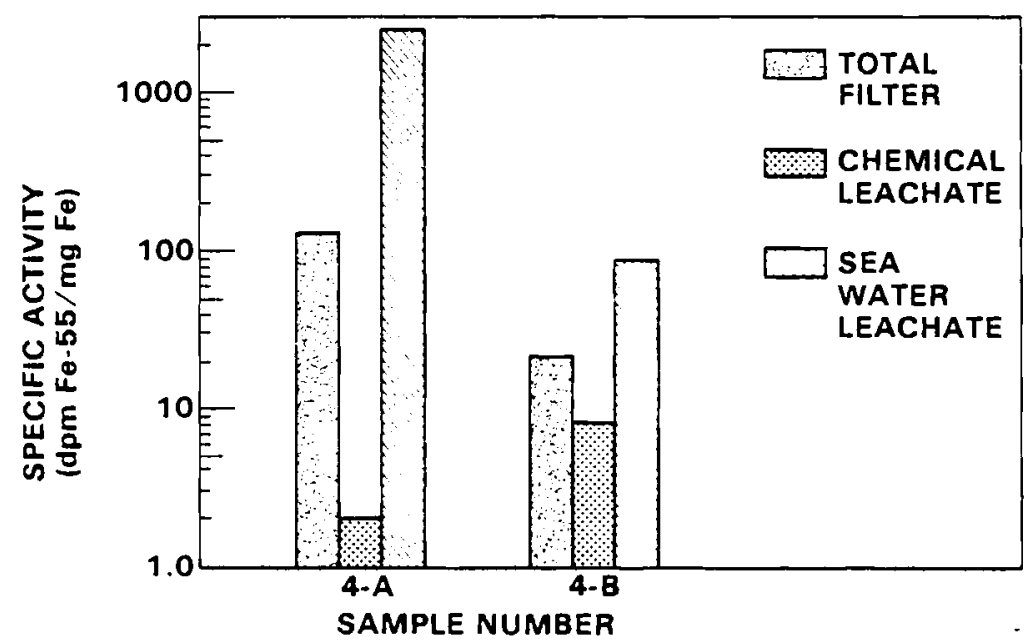

FIGURE 3. ${ }^{55} \mathrm{Fe}$ Specific Activities in Pt. Barrow Aerosols and Aerosol Leachates (1974)

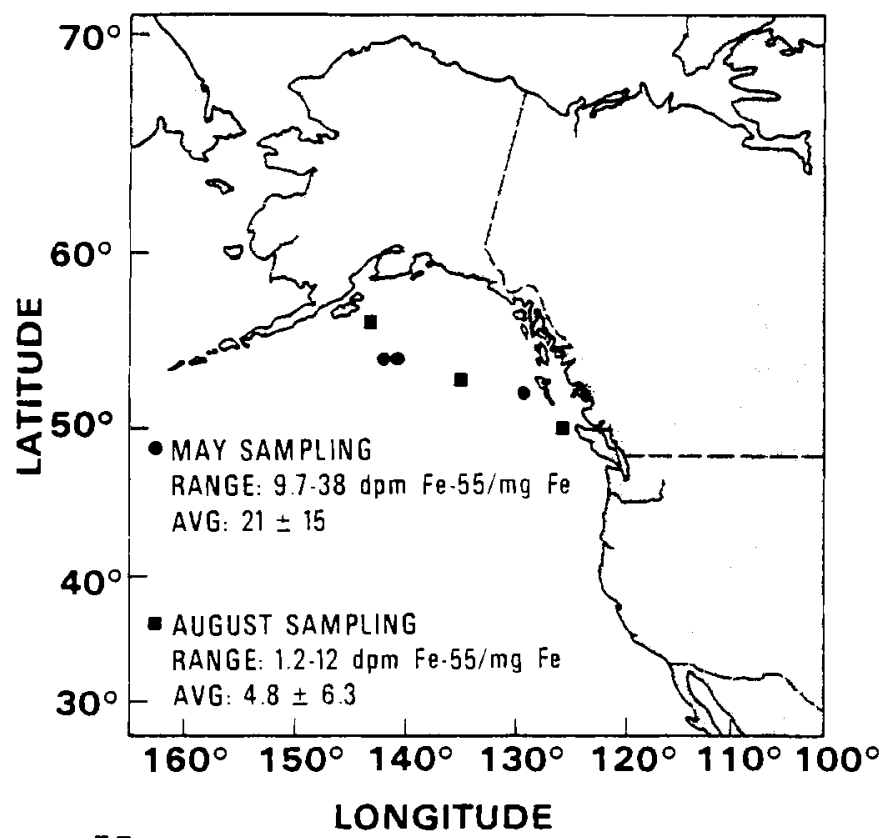

FIGURE 4. ${ }^{55} \mathrm{Fe}$ Specific Activities in Surface water Samples-1974 


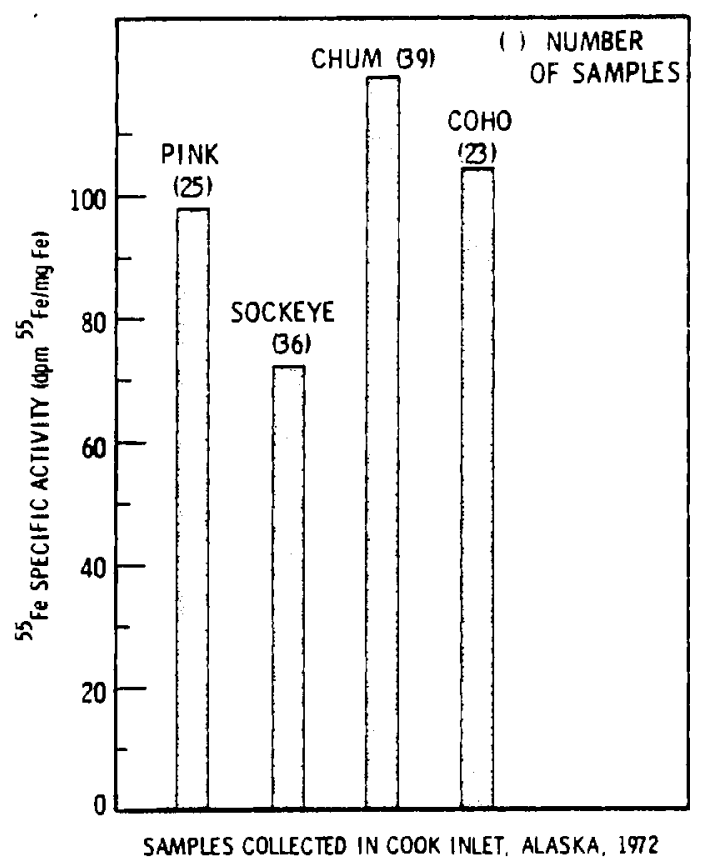

FIGURE 5. Species Comparison of ${ }^{55} \mathrm{Fe}$ Specific Activities in Salmon Muscle Tissues

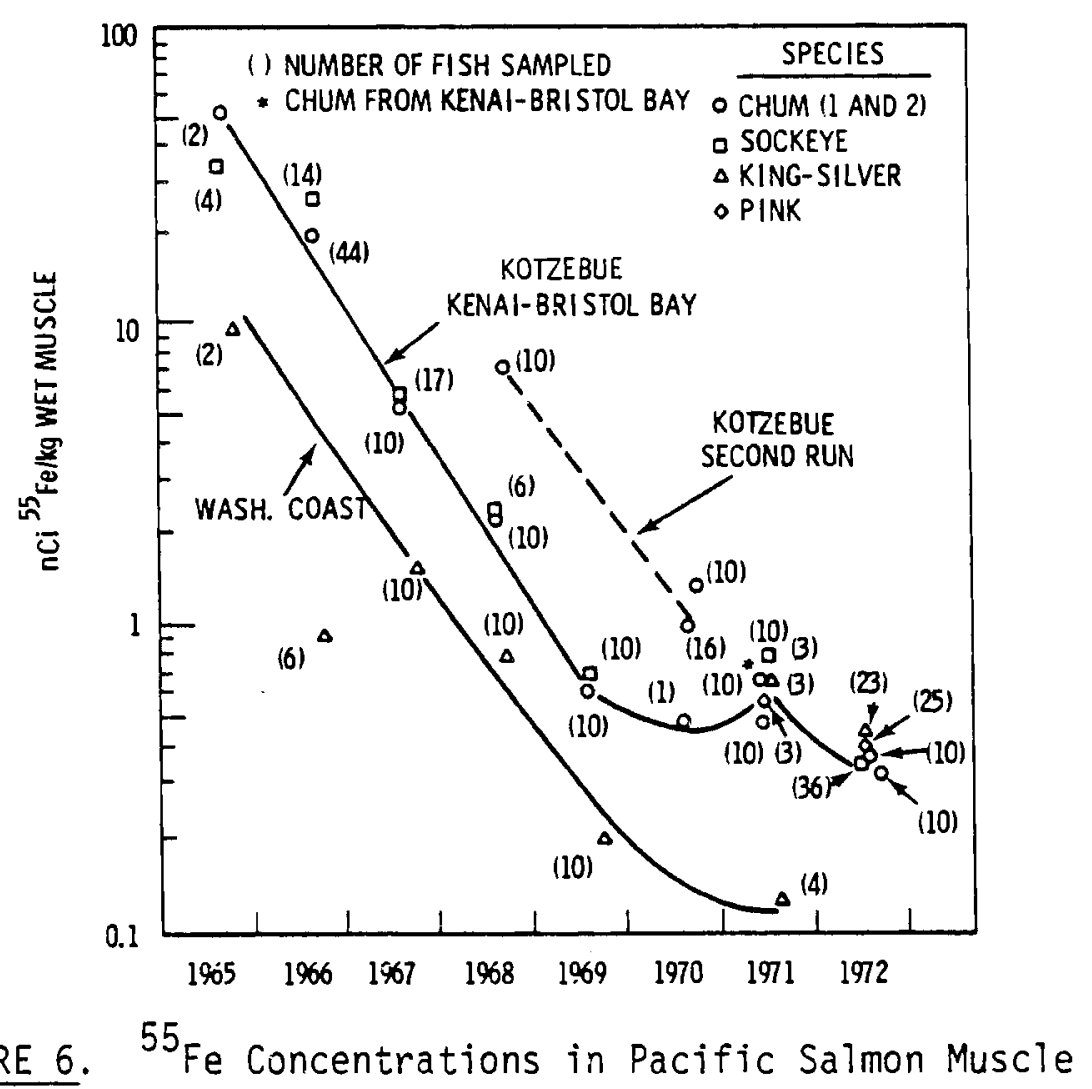




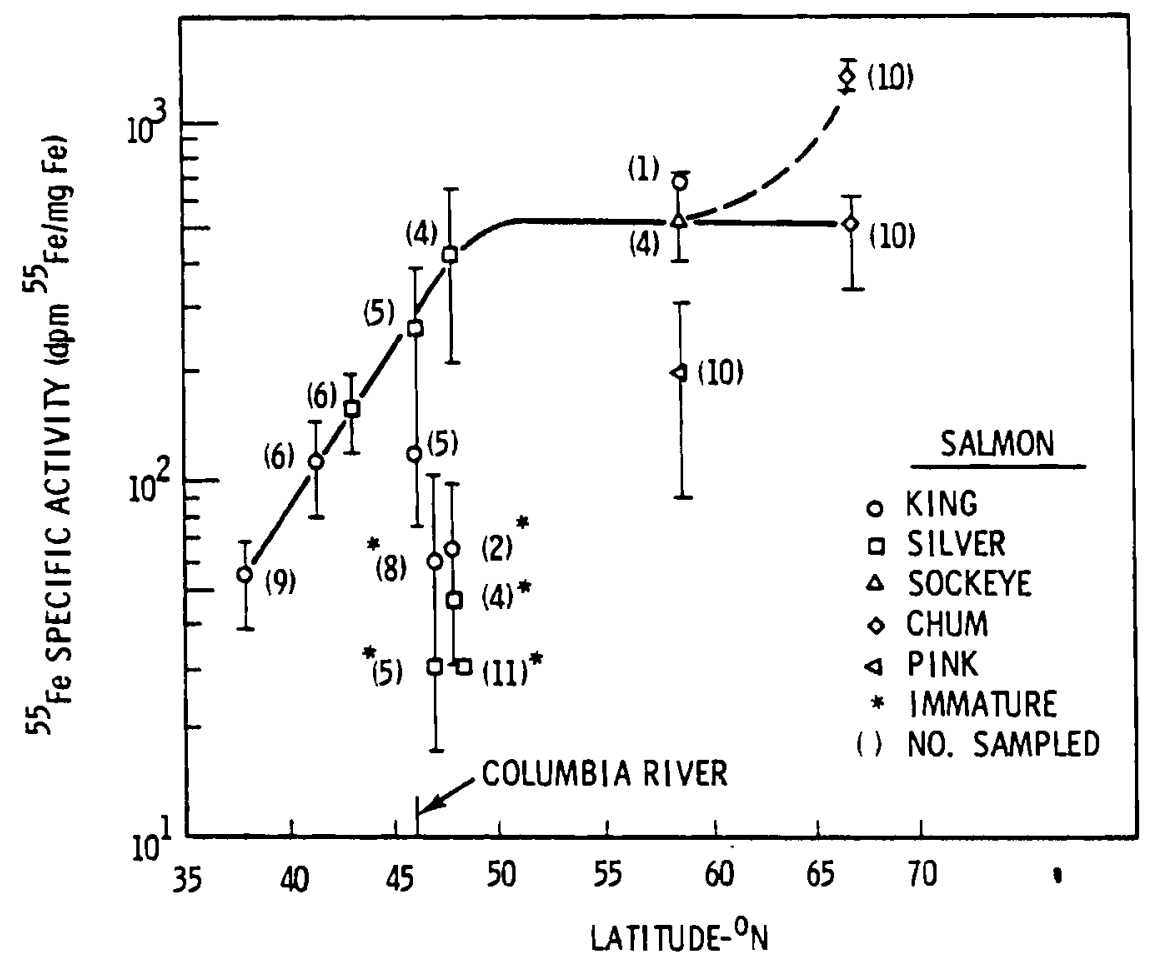

FIGURE 7. ${ }^{55} \mathrm{Fe}$ Specific Activities in Pacific Salmon Muscle Tissue-1968 


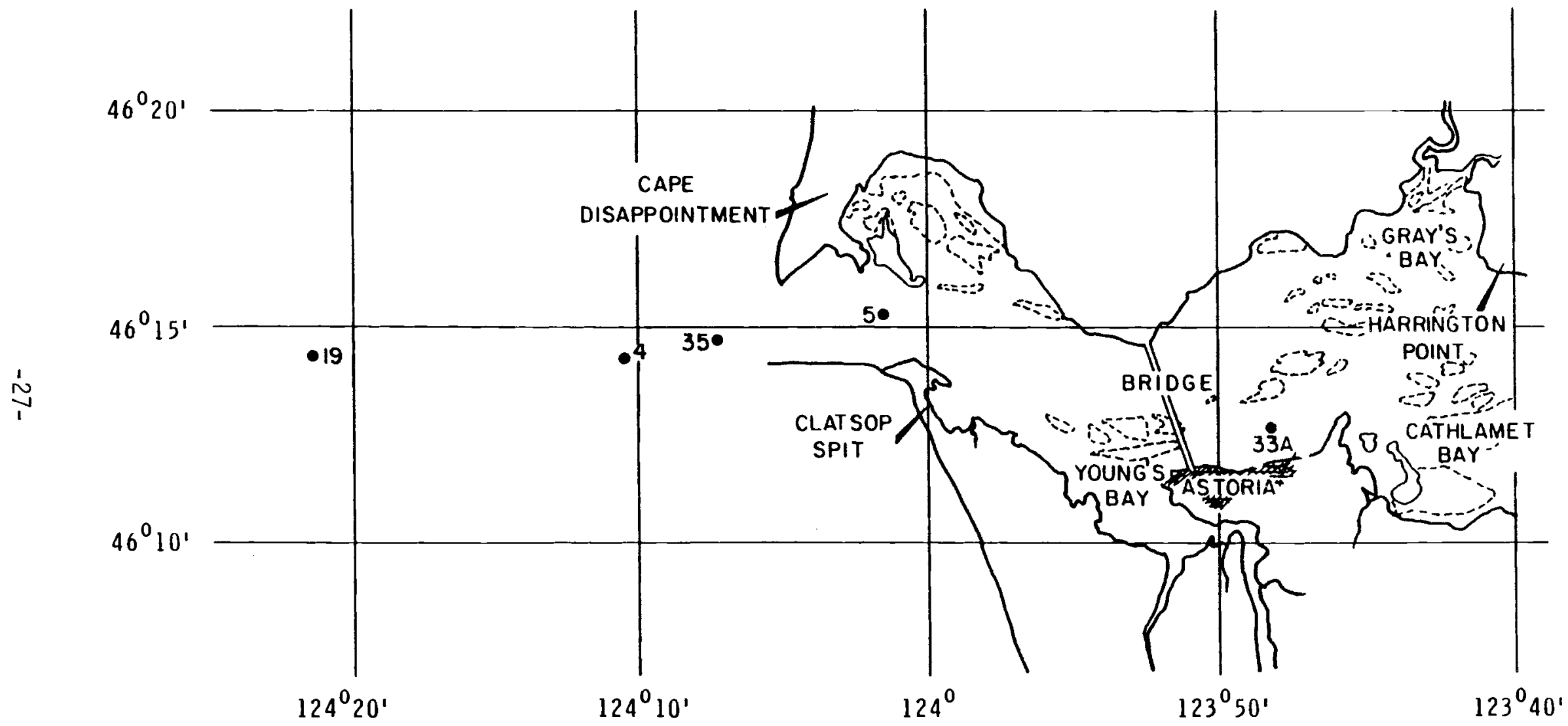

FIGURE 8. Sampling Stations for Collection of Marine and Estuarine Organisms-1968 


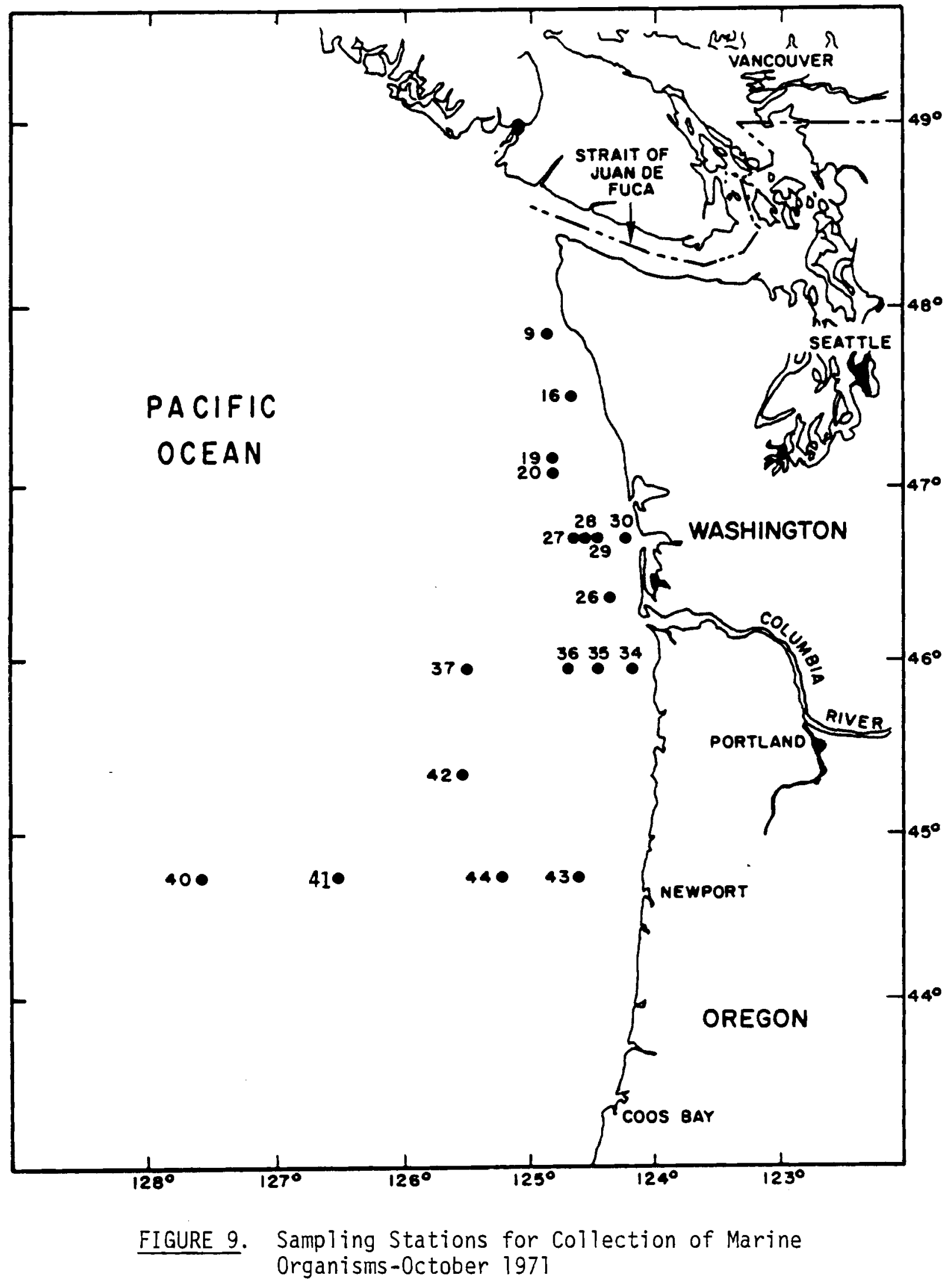




\section{DISTRIBUTION}

No. of

Copies

OFFSITE

A. A. Churm

Department of Energy

Chicago Patent Group

9800 South Case Avenue

Argonne, IL 60439

27 Technical Information Center

Department of Energy

Washington, DC 20545
No. of

Copies

ONSITE

DOE, Richland Operations Office

H. E. Ransom

Battel le-Northwest

J. M. Nielsen

R. W. Perkins

W. D. Felix

C. E. Jenkins (5)

J. C. Langford (5)

W. C. Weimer (5)

Technical Information Library (5) 


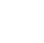

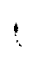

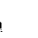

